\title{
The Ultrastructure of Secretory Cells of the Islets of Langerhans in South American Catfish Rhamdia quelen
}

\author{
Laura Luchini, ${ }^{1}$ Gustavo Wicki, ${ }^{2}$ and Luis Alberto Romano ${ }^{3}$ \\ ${ }^{1}$ Dirección de Acuicultura Nación, Paseo Colon 982, Anexo Pesca, 1063 Buenos Aires, Argentina \\ ${ }^{2}$ Centro Nacional de Desarrollo Acuícola (CENADAC), Paseo Colón 982, Anexo Pesca, 1063 Buenos Aires, Argentina \\ ${ }^{3}$ Laboratorio de Imunologia e Patologia de Organismos Aquaticos, Instituto de Oceanografia, \\ Universidade Federal De Rio Grande (FURG), Rua do Hotel 2, 96210-030 Rio Grande, RS, Brazil \\ Correspondence should be addressed to Luis Alberto Romano; dcluis@yahoo.com
}

Received 31 August 2014; Accepted 17 January 2015

Academic Editor: José R. Jaber

Copyright (C) 2015 Laura Luchini et al. This is an open access article distributed under the Creative Commons Attribution License, which permits unrestricted use, distribution, and reproduction in any medium, provided the original work is properly cited.

The present work shows that a detailed description of the ultrastructure of the secretory cells of the South American catfish Rhamdia quelen pancreatic islets is presented. Evidence is offered to support the contention that the $\alpha$-granules consist of a central and an outer portion of different electron densities and solubilities, that the $\delta$-cells are most probably morphologically altered but viable $\alpha$-cells, and that the $\beta$-granules possibly possess a repeating substructure and may therefore represent an intracellular crystalline storage form of insulin.

\section{Introduction}

The islets of Langerhans were discovered in the rabbit by Langerhans in 1869. However, they were reported by Stannius and Blockmann in teleosts about 20 years earlier and therefore are also, although less frequently, referred to as Stannius's or Blockmann's bodies. The islets of Langerhans are of endodermal origin and in most teleosts are found as small bodies scattered in the exocrine portion of the pancreas [1].

The fish does not have a discrete pancreas. Exocrine pancreatic tissue can be found scattered along the intestinal tract. The acinar structure of the exocrine pancreas is very similar to that of mammals and comprises cells with a very dark, basophilic cytoplasm [2]. In actively feeding fish, they contain large numbers of bright eosinophilic, secretory granules. The endocrine pancreatic islet of Langerhans could be distinguished, and tissue encompasses $\alpha$-cells (producing glucagon-like peptide), $\beta$-cells (producing insulin), and $\mathrm{d}$ cells (producing somatostatin) [3]. In mammals and humans most of the earlier electron microscopic descriptions of adult human pancreatic islets have been brief and minor portions of publications are primarily devoted to descriptions of $\beta$ cell tumors or survey articles discussing the comparative morphology of the islets of several species [4].

The fish pancreas does not often prove to be a ready source of tissue for electron microscopic study. The main fish pancreas is both anatomically [5] and developmentally [6] similar to the mammalian pancreas, whereas major differences are apparent in other fish species. In adult zebrafish, the main pancreas contains several principal islets surrounded by exocrine tissue. A tail of single islets embedded in exocrine tissue and fat extends caudally along the intestine. In contrast, the $\beta$-cells of tilapia (another glucose-sensitive teleost fish) reside in islets of Langerhans located along the mesentery that are not surrounded by exocrine tissue $[7,8]$. Rhamdia quelen is a teleost species and is an important species for aquaculture in subtropical climates. $R$. quelen are found from southern Mexico to central Argentina, and husbandry of this species is spreading towards southern Brazil [9].

In the present study we analyze the ultrastructure of the islets of Langerhans and describe in detail the different types of secretory cells in South American catfish R. quelen. 


\section{Materials and Methods}

Four farmed $R$. quelem two females and two males (150.6 \pm $0.5 \mathrm{~g} ; 24.3 \pm 0.2 \mathrm{~cm}$ ) from the Centro Nacional de Desarrollo Acuícola (CENADAC) in the northeastern region of Argentina and stocked in $200 \mathrm{~L}$ tanks where they were acclimated for two weeks before necropsy. Fish were reared with filtered freshwater kept at $25^{\circ} \mathrm{C}$ with a water exchange rate of $100 \%$ per day. Photoperiod was adjusted to $12 \mathrm{~h}$ dark and $12 \mathrm{~h}$ light. They were hand-fed four times per day with commercial diet (Ganave). Fish were euthanized with benzocaine $(500 \mathrm{ppm})$ and necropsied and samples of fat which extends caudally along the intestine were fixed in $10 \%$ buffered formalin, embedded in paraffin, and stained with haematoxylin and eosin ( $\mathrm{H} \& \mathrm{E})$.

Small fragments of tissue were cut into $1 \mathrm{~mm}$ blocks and immediately fixed in phosphate buffered glutaraldehyde $(\mathrm{pH}$ 6.9 at $4^{\circ} \mathrm{C}$ ), washed in Millonig's solution, and postfixed in $1 \%$ osmium tetroxide; the tissue blocks were then dehydrated in a graded series of ethanol-acetone, immersed in propylene oxide, and embedded in Durcupan ACNI (Fluka Chemie A.G., Switzerland). Thin sections were cut with an LKB ultramicrotome and double stained with uranyl acetate and lead citrate before examination in a Jeol JEM-8T electron microscope (Jeol, Tokyo, Japan).

\section{Results}

3.1. Light Microscopy. R. quelen have pancreas scattered throughout the adipose tissue surrounding the common bile duct; this lies within a roughly triangular region outlined superiorly by the stomach, anteriorly by the liver, and inferiorly by the spleen and gallbladder. Each islet of Langerhans is composed of relatively pure islet tissue surrounded by exocrine pancreas (Figure 1). No differences between males and females were observed.

3.2. Electron Microscopy. The $\beta$-cells, which usually occupy the interior of the islets, were commonly, but not always, separated from the exocrine pancreas by the peripherally situated $\alpha$-cells (Figure 2). The ultrastructural appearance of the $\beta$-cells was identical in the samples obtained from the four fish. The distinctive $\beta$-granules were contained in smooth-membraned sacs and were variable in size and shape. Rectangular, square, hexagonal, and irregularly polygonal crystals were visible. Round forms were present but less frequently (Figures 2 to 5). Each granule consisted of one or several crystalline or nonstructured forms of varying size and shape. The choice of fixative did not appear to influence the inner structure of the $\beta$ granules. Within the confines of the enveloping membrane, the area peripheral to the crystals appeared empty or contained a fine flocculent precipitate, regardless of the fixative used. At higher magnifications, a repeating substructure was sometimes visible in those crystals properly oriented with respect to the plane of section (Figures 6 and 7). The numerous mitochondria were dispersed throughout the cell and appeared as rounded or plump filamentous structures. They were larger and more numerous than those of the $\beta$-cell, but usually smaller than those of

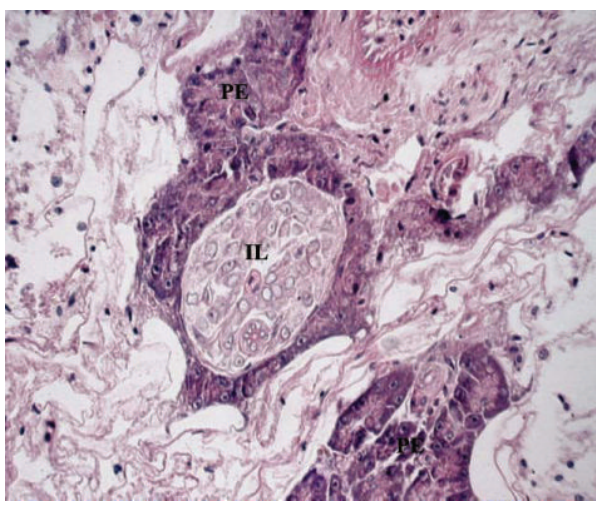

FIGURE 1: Light micrographs of pancreatic tissue scattered throughout the peritoneal adipose tissue. Islets of Langerhans (IL) are composed of relatively pure islet tissue surrounded by exocrine pancreas (PE) (H\&E. X 10).

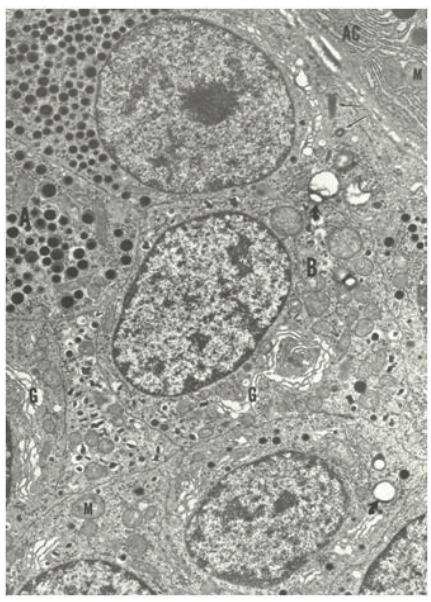

Figure 2: Periphery of normal islet. Pancreatic acinar (AC), $\alpha$ (A), and $\beta$ - (B) cells are visible with their distinctive granules. The preservation of a dense inner core and less dense outer mantle of the $\alpha$-granules and the dilated Golgi structures (G). Ceroid granules (curved arrows) are present in the $\alpha$-cells. Note the centrioles (straight arrows). M: mitochondrion. X 9500.

the pancreatic acinar cells. The numerous mitochondrial cristae were, for the most part, oriented transversely, and mitochondrial granules were present but not prominent. The cisternae of the granular endoplasmic reticulum were usually short or vesicular (Figures 2 to 4 ). The granular endoplasmic reticulum and the free ribosomes were not as prominent a feature of the $\beta$-cells as in the acinar or $\beta$ cells. Those $\beta$-cells with few secretory granules normally were more richly endowed with ribosomes and granular endoplasmic reticulum, which was then more frequently cisternal in configuration (Figure 5).

The Golgi complex was more prominent after aldehyde fixation and the component structures were more dilated (Figure 2). After utilizing these fixatives, dense amorphous material was occasionally visible within Golgi vesicles and may represent immature granules or precursors of the $\beta$ secretory granules. $\beta$-cell nuclei were usually spherical and 


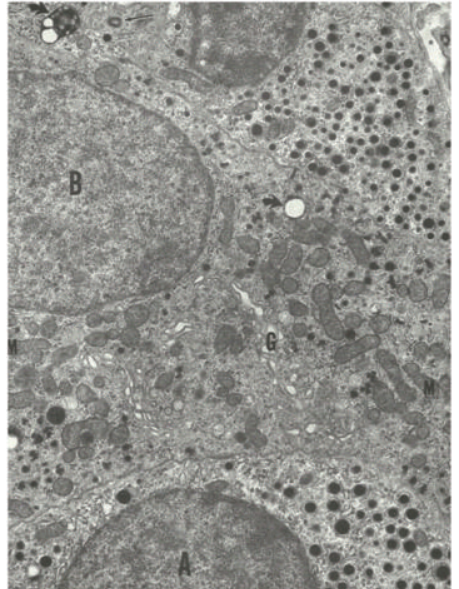

Figure 3: Periphery of normal islet after fixation in osmium tetroxide. $\beta$-granules (B) are unchanged. $\alpha$-granules (A) lack the distinct outer mantle. Mitochondria (M) are larger and more numerous in $\beta$-cells. Both cell types contain ceroid granules (curved arrows). A centriole is indicated by straight arrows. G: Golgi complex. X 9500.

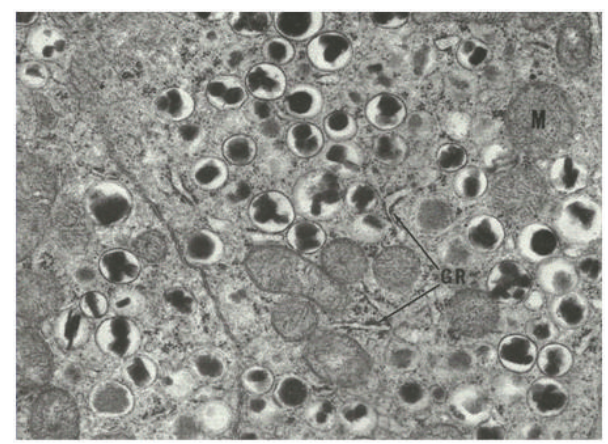

FIGURE 4: Portions of two $\beta$-cells illustrating the variation in appearance of the $\beta$-granules. Rounded and angular configurations are visible. Granular endoplasmic reticulum (GR) is sparse. M: mitochondrion. X 21.000 .

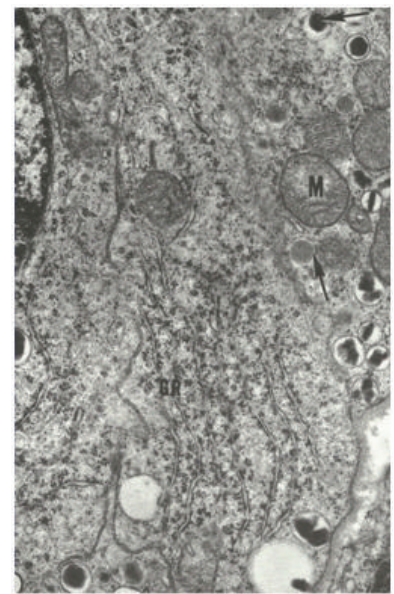

FIGURE 5: $\beta$-cell with long parallel profiles of the granular endoplasmic reticulum (GR). This pattern is not frequent in the resting $\beta$ cell. Arrows indicate $\beta$-granules with different "staining" intensity. $\mathrm{N}$ : nucleus; M: mitochondria. X 21.000.

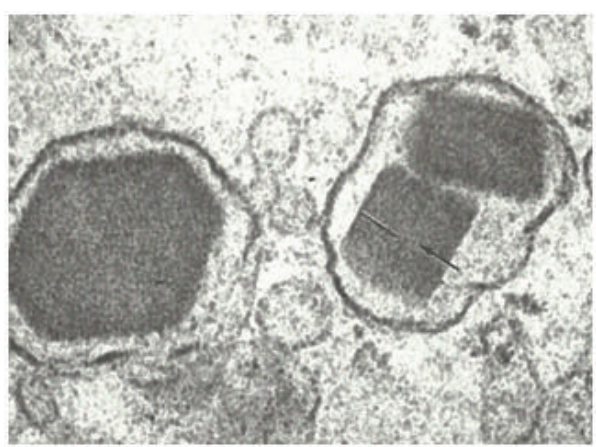

FIGURE 6: $\beta$-granules having a rectangular or hexagonal configuration and possibly an inner repeating substructure, parallel to the long axis of the rectangular granules (arrows). X 206.000.

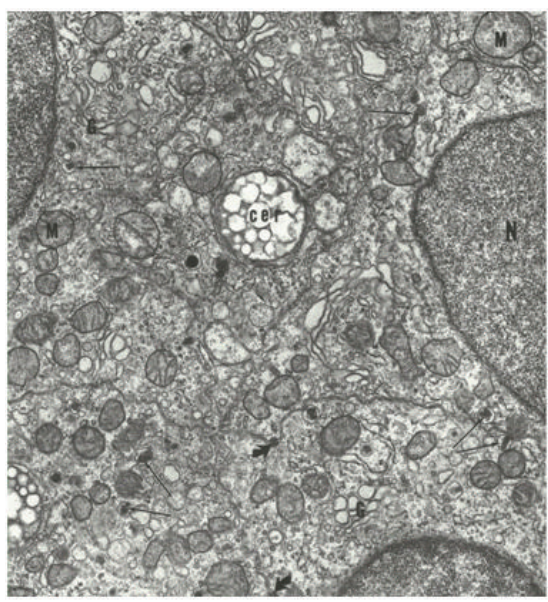

FIGURE 7: Several $\beta$-cells in an islet, $\beta$-granules (straight arrows), and granular endoplasmic reticulum are reduced, but other organelles are normal. Two small desmosomes are indicated (curved arrows). G: Golgi complex; M: mitochondrion; N: nucleus; cer: ceroid granules. X 13.700 .

relatively smooth in contour. The cell membrane of adjacent islet cells was in close apposition to, although not frequently joined by, desmosomes. At the junction of three or more cells, limiting membranes were often convoluted, with tortuous interdigitations of the cells (Figures 2 and 9). Multivesicular cytoplasmic inclusions resembling ceroid were conspicuous in most $\beta$-cells (Figures 2, 7, 9, and 8). The appearance and frequency of these inclusions were not appreciably affected by the primary use of osmic acid or aldehyde as a fixative, and there was no apparent relationship between the presence of these granules and the morphologic evidence of physiologic activity by the cells. The ultrastructure of the $\alpha$-cells was the same in all four tissue samples. The size and shape of these cells and of their nuclei were not significantly different from those of normal $\beta$-cells (Figures 2 and 7). Although one occasionally found an $\alpha$-cell with an irregularly shaped or an indented nucleus, this did not occur with enough frequency to serve as a useful differentiating criterion. The $\alpha$ cell cytoplasmic granules were preserved by primary osmium fixation as dense, spherical bodies of variable size and were 


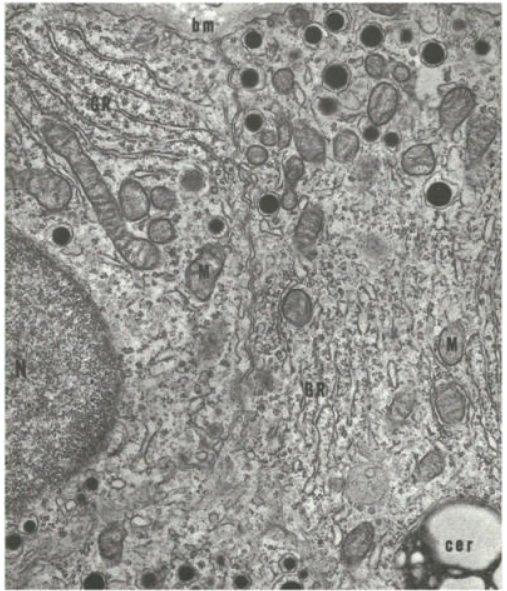

Figure 8: $\alpha$-cells; only the dense inner core of the cytoplasmic granule is visible. The diameter of the granules is variable within each cell. Granular endoplasmic reticulum (GR) is more prominent and parallel cisternae more frequent in the $\alpha$-cells than in the $\beta$ cells. bm: basement membrane; $\mathrm{M}$ : mitochondrion; $\mathrm{N}$ : nucleus; cer: ceroid granules. X 21.000 .

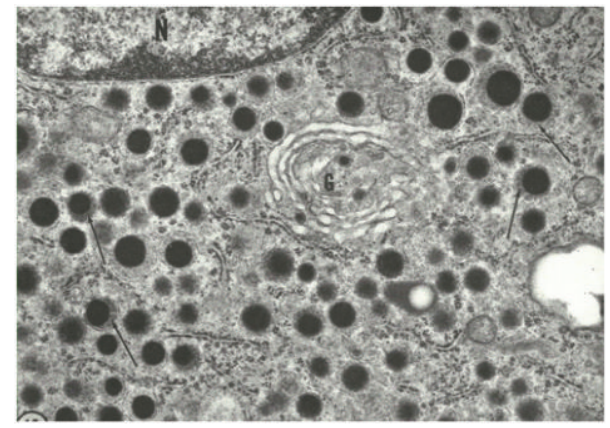

FIGURE 9: $\alpha$-cytoplasmic granules fill the smooth enveloping sac. The outer mantle (arrows) is less electron-opaque. The Golgi complex $(\mathrm{G})$ contains three small granules. N: nucleus. X 21.000.

contained within loosely fitting smooth-membraned sacs (Figures 7 and 9). They were larger than the $\beta$-granules, but considerably smaller than the zymogen granules of the acinar cells (Figure 2). The slender, elongated mitochondria were moderate in number and smaller than those of the $\beta$-cells and possessed cristae which were usually oriented transversely. The granular endoplasmic reticulum was often cisternal in configuration and more abundant than in the $\beta$-cells (Figure 9). The Golgi complex, when visible, was of moderate proportions. Dense amorphous materials within Golgi vesicles and cisternae, presumably the precursors of the secretory granules, were more common in $\alpha$-cells than $\beta$ cells (Figure 10). Ceroid bodies, although frequently visible, were less numerous than in the $\beta$-cells (Figures 2 and 3 ). The sacs in which the $\alpha$-granules are situated appeared, therefore, to be completely filled, and it was concluded that the granules consist of a rounded inner dense core and an outer less electron-dense mantle which was absent after osmium fixation (Figures 3 and 9) and therefore, perhaps,

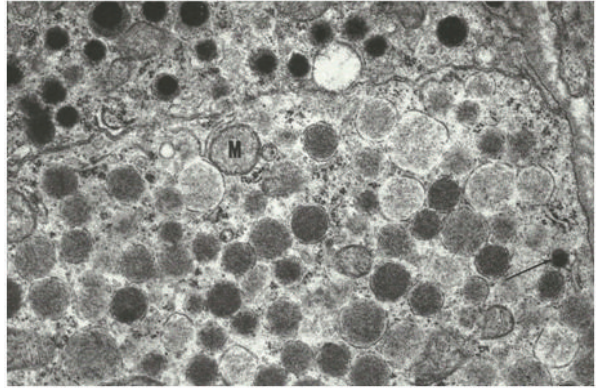

FIgURE 10: Normal $\alpha$-cell. With the exception of one granule (arrow), the cytoplasmic granules of the lower cell lack the inner and outer zones of differing electron density. Other organelles are unchanged. M: mitochondrion. X 21.000.

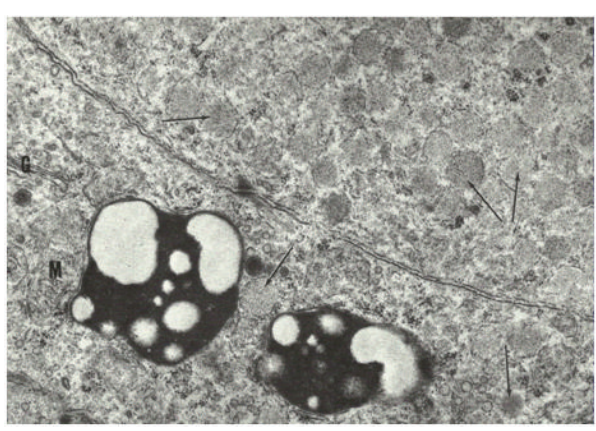

Figure 11: The $\delta$-cell with granules with differing electron density (arrows). Ceroid granules are clearly visible and not abnormal. G: Golgi complex; M: mitochondrion. X 21.000.

more soluble. No consistent substructure was visible within either the inner or the peripheral portions of the $\alpha$-granules. At no time were cells seen which could be interpreted as transition forms between $\alpha$-cells and $\beta$-cells. The $\alpha$-granules, including both the outer and inner more dense portions, were comparable in total size to the " $\delta$-granules." Moreover, intermediate cells are present which contained granules of both types suggesting that the $\delta$-cells were in fact modified $\alpha$ cells (Figure 10). The $\delta$-cells were visualized, although almost always located among the $\alpha$-cells, and have been identified and distinguished ultrastructurally from $\alpha$-cells on the basis of the lower electron density and the larger overall size of their secretory granules. Moreover, intermediate cells are present which contained granules of both types suggesting that the $\delta$-cells were in fact modified $\alpha$-cells (Figure 11).

Although an inverse relationship existed between the number of secretory granules and the prominence of the Golgi complex and granular endoplasmic reticulum, no pattern of release of $\alpha$ - or $\beta$-granules was observed. A thin basement membrane and varying amounts of connective tissue usually separated the pancreatic islets from adjacent acinar cells (Figure 2). Occasionally, however, no basement membrane intervened between islet and acinar cells which were then separated only by the narrow interstitial space. The fenestrated capillary endothelial cells were always separated from them by at least the capillary basement membrane 
(Figure 9). Other supporting elements, including collagen and elastic tissue components, were also sometimes present. No differences between males and females were observed.

\section{Discussion}

Fish $\beta$-cells are readily distinguished from the $\alpha$-cells by the morphology of the secretory granules. The frequent presence of angular subunits and the apparent repeating substructure suggest a crystalline nature for the $\beta$-granules. Attempts to resolve and measure the dimensions of a crystal lattice have not yet been successful. When secretory granules were visualized in the vicinity of the Golgi complex, crystalline subunits were not usually observed. It is tempting to speculate, therefore, that the noncrystalline granules or the amorphous material within the Golgi complex represents a different chemical or physical form of insulin or insulin protein complex than the crystalline subunits of the granule. It is not known whether these different morphologic forms within the $\beta$-granules have different solubilities and perhaps different patterns orates of release in response to physiologic demand. Secretory granules were not observed in the cisternae or vesicles of the granular endoplasmic reticulum. It is assumed that, as with other protein secreting cells, the Golgi complex functions to concentrate or "package" the product synthesized in the granular endoplasmic reticulum [10-12]. It would logically follow that the smooth-membrane sacs in which the secretory granules are contained are derived from Golgi membranes rather than from the granular endoplasmic reticulum.

The $\alpha$-cells with their large, rounded, dense secretory granules are quite similar to $\alpha$-cells of other species. Although the $\alpha$-cells granules vary widely in dimension, most cells appeared to possess an assortment of different sized granules, thereby precluding a subclassification of this cell type as has been suggested for other species [13]. At this time, no physiologic data have been published to support the existence of the " $\delta$-cell" in the fish pancreatic islet. The various protagonists have supported the existence of the $\delta$-cells with data based upon light microscopic examinations of capricious silver, phosphotungstic acid-hematoxylin, and other granule stains or electron microscopic studies of poorly preserved tissues. The micrographs presented here support the opinion considered by Bloom [14] in 1931 and subsequently by Gomori [15] in 1941 that $\delta$-cells might represent modified $\alpha$-cells.

The transition from the typical $\alpha$-granule, with inner dense and outer less dense portions, to a $\delta$-granule of approximately the same size, with uniform but decreased density, is often accompanied by a gradual loss of morphologic integrity or staining intensity of mitochondria, Golgi complex, and the membranous components of the granular endoplasmic reticulum. The intact and viable-appearing nuclei, as well as the persistence of small numbers of free ribosomes and ceroid bodies, suggest that the so-called $\delta$-cells are viable even at the presumed end stage of this transition, that is, where secretory granules themselves are no longer visible and all cytoplasmic organelles other than ceroid granules and ribosomes are absent. Lacking physiologic data assigning a function to the $\delta$-cells and in the absence of more compelling morphologic evidence for a separate cell type, it is hoped that the presentation here of a probable transition from $\alpha$-cells to $\delta$-cells will be accepted as the most likely explanation of the third granular cell of Bloom in human [14]. The significance of these viable but altered $\alpha$-cells is not known. Although $\alpha$ and $\beta$-cells, singly or in small clusters, may be seen within acini and ducts, at no time in any of the four pancreatic samples studied were any intermediate forms between acinar and islet or duct and islet cells seen, as had been suggested by Nakamura and Yokote (4).

\section{Conflict of Interests}

The authors declare that there is no conflict of interests regarding the publication of this paper.

\section{Acknowledgment}

L. A. Romano received productivity research fellowships from Brazilian Council of Research, $\mathrm{CNPq}$ (Process no. PQ 301002/2012-6).

\section{References}

[1] F. Takashima and T. Hibiya, An Atlas of Fish Histology, Kodansha, Tokyo, Japan, 2nd edition, 1995.

[2] R. J. Roberts and A. E. Ellis, "The anatomy and physiology of teleosts," in Fish Pathology, R. J. Roberts, Ed., pp. 12-54, WB Saunders, Philadelphia, Pa, USA, 3rd edition, 2001.

[3] C. M. Morrison, B. Pohajdak, J. Tam, and J. R. Wright Jr., "Development of the islets, exocrine pancreas, and related ducts in the Nile tilapia, Oreochromis niloticus (Pisces: Cichlidae)," Journal of Morphology, vol. 261, no. 3, pp. 377-389, 2004.

[4] S. S. Shorr and F. E. Bloom, "Acino-insular cells in normal rat pancreas," Yale Journal of Biology and Medicine, vol. 43, no. 1, pp. 47-49, 1970.

[5] S. Chen, C. Li, G. Yuan, and F. Xie, "Anatomical and histological observation on the pancreas in adult zebrafish," Pancreas, vol. 34 , no. 1, pp. 120-125, 2007.

[6] A. B. Ward, R. M. Warga, and V. E. Prince, "Origin of the zebrafish endocrine and exocrine pancreas," Developmental Dynamics, vol. 236, no. 6, pp. 1558-1569, 2007.

[7] B.-Y. Xu, C. M. Morrison, H. Yang, and J. R. Wright Jr., "Tilapia islet grafts are highly alloxan-resistant," General and Comparative Endocrinology, vol. 137, no. 2, pp. 132-140, 2004.

[8] J. R. Wright Jr., C. Abraham, B. C. Dickson, H. Yang, and C. M. Morrison, "Streptozotocin dose-response curve in tilapia, a glucose-responsive teleost fish," General and Comparative Endocrinology, vol. 114, no. 3, pp. 431-440, 1999.

[9] L. Luchini, Manual para El Cultivo de Bagre Sudamericano (Rhamdia Sapo), RLAC/90. PES, Food and Agriculture Organization of the United Nations, Rome, Italy, 1990.

[10] T. T. Bizuayehu and I. Babiak, "MicroRNA in teleost fish," Genome Biology and Evolution, vol. 6, no. 8, pp. 1911-1937, 2014.

[11] J. M. Conlon, "Molecular evolution of insulin in nonmammalianvertebrates," The American Zoologist, vol. 40, no. 2, pp. 200-212, 2000.

[12] J. R. Wright Jr., A. Bonen, J. M. Conlon, and B. Pohajdak, "Glucose homeostasis in the teleost fish tilapia: insights from 
brockmann body xenotransplantation studies," Integrative and Comparative Biology, vol. 40, no. 2, pp. 234-245, 2000.

[13] F. Caramia, B. L. Munger, and P. E. Lacy, "The ultrastructural basis for the identification of cell types in the pancreatic islets I. Guinea pig," Zeitschrift für Zellforschung und Mikroskopische Anatomie, vol. 67, no. 4, pp. 533-546, 1965.

[14] V. V. Bloom, "A new type of granular cell in the islets of Langerhans of man," The Anatomical Record, vol. 49, no. 4, pp. 363-371, 1931.

[15] G. Gomori, "Observations with differential stains on human islets of Langerhans," The American Journal of Pathology, vol. 17, no. 3, pp. 395-409, 1941. 

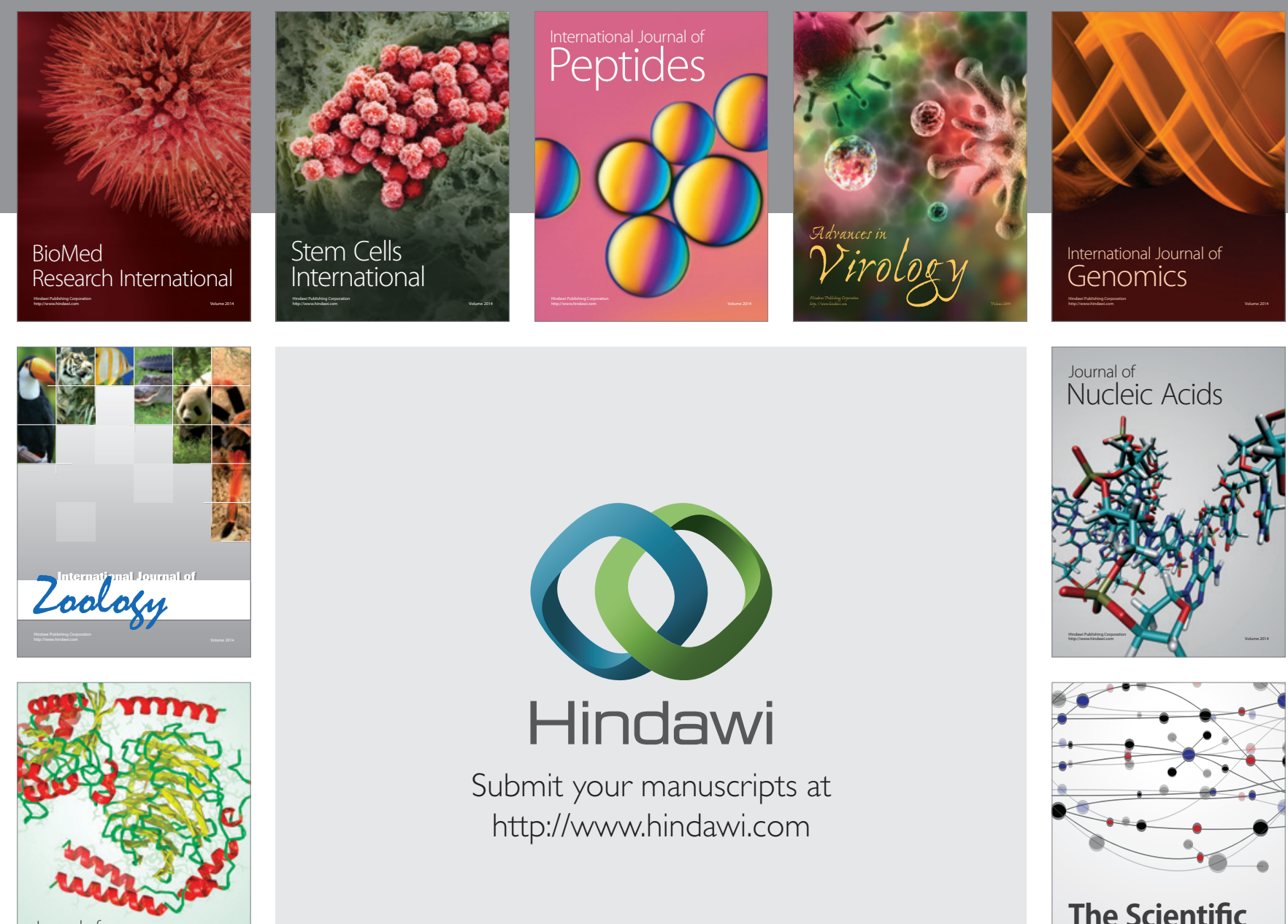

Submit your manuscripts at

http://www.hindawi.com

Journal of
Signal Transduction
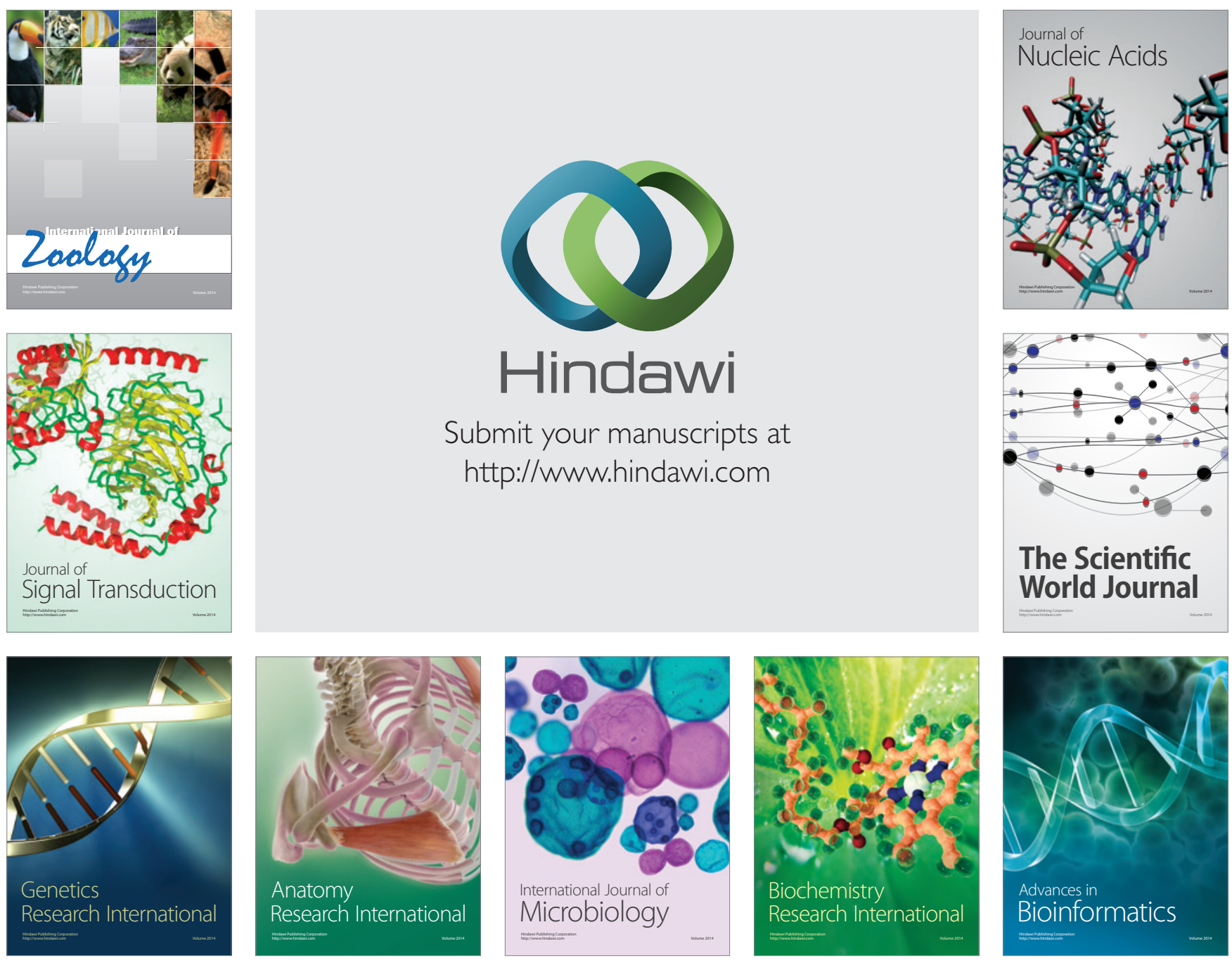

The Scientific World Journal
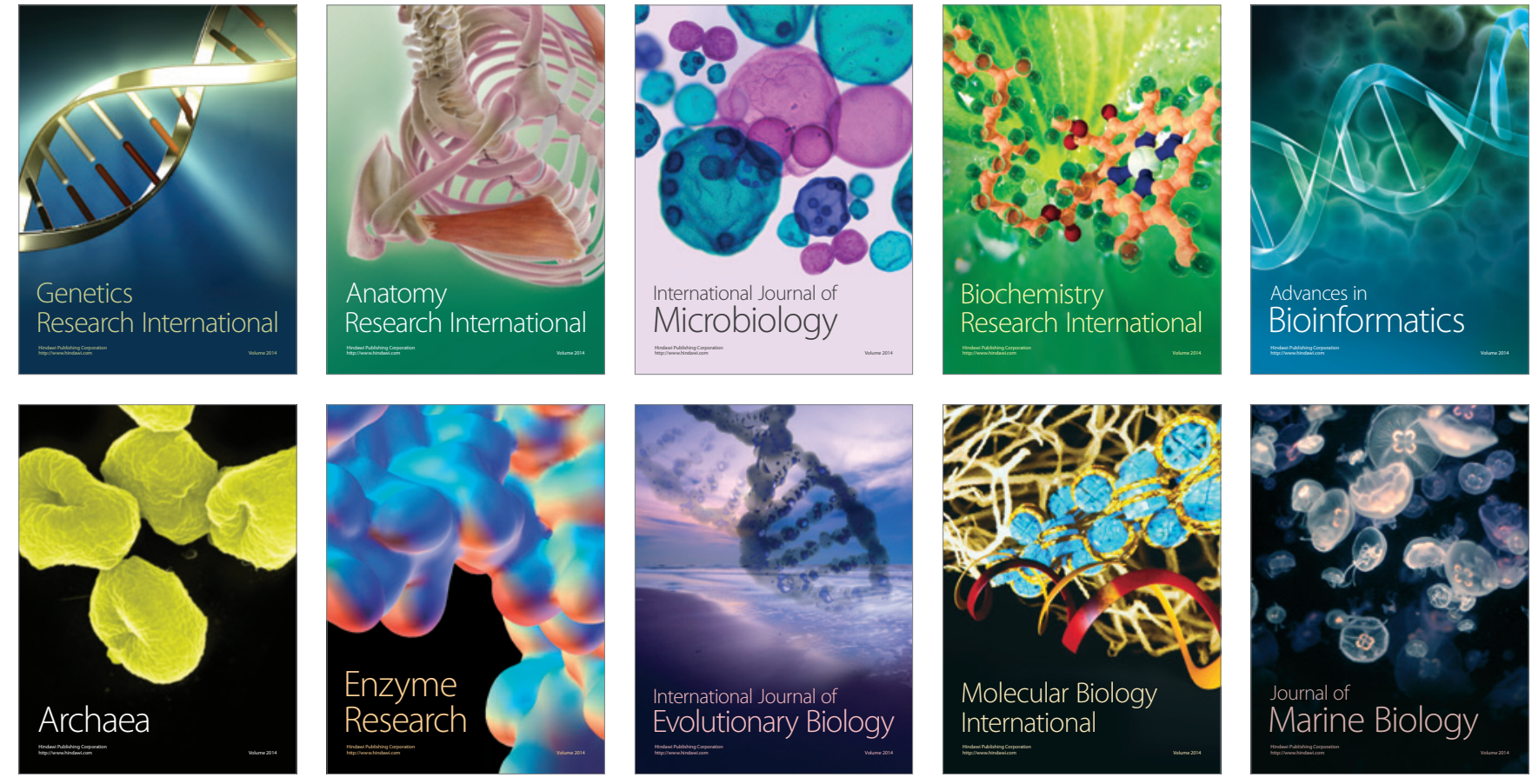